\title{
An Analytical Study of the Functioning and the Problems of the Powerloom Industry in Maharashtra with Special Reference to Malegaon Dist. Nashik
}

\author{
Arif Anjum and D. V. Thakor
}

\begin{abstract}
Indian textile industry has an awesome existence in the Indian economy. It is second largest employer after Agriculture in India. It is one of the largest in the world with a massive raw material and textiles manufacturing base. Currently, it contributes about 14 percent to industrial production, 4 percent to the GDP, and 17 percent to the country's export earnings. Around 35 million people are directly employed in the textile manufacturing activities. Indirect employment including the manpower engaged in agricultural based raw-material production like cotton and related trade and handling could be stated to be around another 60 million. The India Textile Industry has three main segments mill sector, handloom sector and decentralised powerloom sector. This paper analyses the functioning and the problems of powerloom industry.
\end{abstract}

Index Terms-Indian Textile Industry, Powerloom Industry

\section{INTRODUCTION}

The Indian textile industry consists of three distinct sectors representing broadly three levels of technology and Organisation, namely, mills, Powerlooms and handloom. The handloom sector is the oldest among them with a long tradition of excellence and unrivalled craftsmanship. The mill sector is over one hundred and fifty years old with about 1834 textile mills, installed capacity of 37.07 million spindles and $4,89,718$ rotors. The last to appear on the scene is the powerloom sector which over the last three decades has come to occupy a prominent position with a 22.05 laky powerlooms in the country.

The growth of the powerloom industry started with the loosing of the ground by the textiles mills. The powerlooms were first introduced in India in the starting of the $20^{\text {th }}$ century During the great depression period (1929 to 1933) the mill sector started to discard the powerlooms. The labours of the textile mills refurbish the discarded powerlooms and started the small units as a small and cottage industry. It was the existence of the decentralised sector of powerloom industry.

The other reason for the growth of the powerloom industry

Manuscript received April 26, 2011.

Arif Anjum is a PhD student at Research Centre in Commerce, M.S.G. Arts Science \& Commerce College, Malegaon Dist. Nasik M.S. India (affiliated to University of Pune, Pune). He is also editor of many national and international journals. He obtained his Masters Degree in Commerce and in Economics also. He is also AWARDEE of junior Research Fellow (JRF) from UGC, Govt. of India. (editorresearcher@gmail.com)

D. V. Thakor is Associate Professor and Head of Dept. of Commerce at M.S.G. Arts Science \& Commerce College, Malegaon Dist. Nasik M.S. India (affiliated to University of Pune, Pune) His research area is Business Practices and Marketing. was conversion of handlooms into powerlooms. In 1954, for the economic development of the handloom weavers, the scheme of conversion of handloom to powerlooms was introduced by the government. In 1930 there are about 3000 powerlooms in the country while at the end of 2008-2009 it raised to about 22.05 laky powerlooms in the country.

The powerloom industry is spread in all over India. The major states are Maharashtra, Tamil Nadu, Gujarat, Andhra Pradesh, Uttar Pradesh, Madhya Pradesh, Punjab, Rajasthan, Karnataka, and Hariana. Maharashtra occupies a premier position in the textile map of the country. There are about 11.06 powerlooms in Maharashtra. The state of Maharashtra has the prominent textile centres such as Bhiwandi, Malegaon, Ichalkaranji, Solapur, Nagpur etc. Powerloom industry in Maharashtra is more rapidly growing industry than in other states in India. The Powerloom industry is the biggest small scale industry of Maharashtra.

\section{STATEMENT OF THE PROBLEM}

The present study is an attempt to analyse the functioning of the powerloom industry \& assessing the problems suffered by the industry in Maharashtra in general and Malegaon in particular. The study is expected to reveal the deficiencies if any, and enable to suggest appropriate measures for the problems of the industry, and there by serve the interest of weavers, traders \& consumers more effectively.

\section{SCOPE OF THE STUDY}

The present study is integrated and comprehensive study on powerloom industry of Malegaon projecting its detailed picture. This may help to enlighten the pathways to action and give broad indication for different policy options. The present study is an attempt to discover the factors that accounts for its vitality, strength and weakness.

\section{OBJeCTIVES}

The study seeks to examine \& focusing, considering the facts in a comprehensive manner the state of functioning \& problems of Powerloom industry in the state of Maharashtra emphasising Malegaon to the following context.

1) To study the nature, administration, status and scope of the Powerloom Industry of Maharashtra with special reference to Malegaon.

2) To analyse the Powerloom Industry of Malegaon in the context of Socio- Economic Development. 
3) To suggest measures for modernisation in respect to technology upgradation, quality control and competitive marketing to face the challenges of the globalization.

4) To examine production pattern and the cost structure of Powerloom industry.

5) To analyse the problems \& issues of Powerloom industry.

6) To provide concrete recommendations for overall development of Powerloom industry and to enhance its efficiency.

\section{REVIEW OF LITERATURE:}

In 1949 M.M. Mahta studied the trends in size of cotton spinning and weaving units at different clusters like Bombay (Mumbai), Ahmedabad, Madras (Chennai) and other important clusters of the country for the period of 1905 to 1944. He emphasised on the size of the industrial units in weaving industry. S.V. Chorghade (1976) in his research work studied the "Powerloom Industry In Maharashtra". Maharashtra state has a lion's share in the growth and development of the Powerloom industry. He attempted to undertake a detailed study of structure and problems of Powerloom industry in Maharashtra. P.R. Ojha (1978) studied the dividend distribution of 51 cotton textiles companies. He analysed the dividend distribution of the companies on the basis of size, region, ownership group, management pattern and age of the companies. $R$. R. Ansari (1984) in his research work explained the marketing problems of Powerloom industry in Malegaon City of Nashik District. He has very specifically indicated the marketing problems faced by the Powerloom industry. Omkar Goswami (1985) has made an analysis of demand and supply in the cotton textile industry. According to him, only the Powerloom sector and the pure spinning units seem to be doing well. Sixty five to seventy percent of composite mills and the entire handloom sector are sick. V. S. Mangnale (1987), in his research work about labour absenteeism in Textile Industry in Solapur, attempted to identify the causes of labour absenteeism in textile town of Solapur. He studied the nature of absenteeism and highlights the different dimensions of the problem. B.M. Dolle (1992) in his research work revealed the socio economic problems of powerloom industry in Malegaon. He studied the powerloom industry of Malegaon for the period of 1935 to 1985 . The main conclusions of the study are; the powerloom industry in Malegaon has seen many ups and downs in its development and it is one of the important industries of Maharashtra. The powerloom industry in Malegaon has glorious past and bright future. There are many socio economic problems in the powerloom industry of Malegaon like scarcity of the finance, marketing problems, labour problems etc. D. C. Mathur in his book "Personnel Problems and Labour Welfare A study of cotton textile industry (1993)" had explained about personnel management in the cotton textile industry. He explained that for the economic results the management of personnel is very important. B. Sabhoo (1993) in his research work he explained the problems and prospects of textile industry with special reference on the productivity of large and small scale textile industries. He attempted to throw light on the factor productivity of the textile industry.

\section{RESEARCH METHODOLOGY:}

The study involves the data collected from the primary as well as secondary sources. The primary data was collected primarily from powerloom units and powerloom workers, constituting the major source of data for the study. For this purpose two separate comprehensive questionnaires, intended to be the principle instruments for obtaining necessary information, were prepared for (1) Powerloom Units and (2) Powerloom workers. The questionnaires were designed in such a way to meet the requirements for the study. The questionnaires were consisting of all aspects of the functions and problems of Powerloom industry in Malegaon.

Secondary data relating to powerloom industry was collected from Reports of Ministry of Textile, New Delhi, Office of the Textile Commissioner, Mumbai, PDEXIL (Powerloom Development Export Promotion Council) Mumbai, Powerloom Service Centre, Malegaon, Directorate of Textile and Co-operation, Govt. of Maharashtra, Nagpur and records of Malegaon Municipal Corporation, Labour Office, Govt. of Maharashtra, and Malegaon.

Besides them the secondary data about Powerloom industry has been taken from published and unpublished literature.

\section{HYPOTHESES ANALYSIS}

The first hypothesis that "The Powerloom sector has tremendous potential and strength to meet the future challenges as it has proven its performance and emergence of Powerloom sector has transformed an art into a modern industry" has been proved true by the analytical study of the statistical data about powerloom industry.

The analytical study of the statistical data about decentralised powerloom sector shows that the industry's growth is remarkable. The production trend of powerloom industry continues in the right direction. It produces around thirty thousand millions square meters annually and employing about 55 lakh workers. The Indian powerloom industry is not only self sufficient in the raw materials but also it is one of the suppliers of the raw material in the global textile market. More than $40 \%$ of the cloth that goes into exports originates from this sector. The modernisation process by the government has widened the scope of the powerloom industry to further their activity and profitability. Since 2002-03, 30657 Semi Automatic, 10303 Automatic and 26972 Shuttleless looms were installed under modernisation scheme. The sector today not only fulfils the need of the domestic market but it exports to major countries across the world.

The study of the powerloom industry proved that the powerloom industry has tremendous potential and strength to meet the future challenges and the emergence of powerloom sector has transformed an art into a modern industry.

1) The second hypothesis that "The terms of employment of powerloom workers need updation" has been proved 
true by the study of terms of employment of workers in Malegaon.

The above said hypothesis was tested with the help of ChiSquare Test. The relevant variables were selected and three formulated sub-hypotheses were tested.

The first formulated hypothesis "Workers' job security is dependent on working conditions of the factory" has been found valid. The critical value of the Chi Square at 0.05 level of confidence for 9 degree of freedom was 16.919 which is less than calculated value of Chi Square i.e. 96.471 hence the null hypothesis was rejected.

The second formulated hypothesis “Workers' Satisfaction with wages is dependent on satisfaction of job" has also been found valid. The critical value of the Chi Square at 0.05 level of confidence for 9 degree of freedom was 16.919 which is less than calculated value of Chi Square i.e. 109.083 hence the null hypothesis was rejected.

The third formulated hypothesis “Workers' satisfaction with wages is dependent on Welfare Facilities" has been found valid. The critical value of the Chi Square at 0.05 level of confidence for 9 degree of freedom was 16.919 which is less than calculated value of Chi Square i.e. 116.685 hence the null hypothesis was rejected.

It is clear that the owners of powerloom units failed to provide basic amenities to the workers. The majority of the workers are not satisfied with the working conditions of the factory. They are working with dust and fumes, no proper lighting and ventilation, ignorance of cleanliness, no care on hygienic conditions and no safety measures to avoid accidents. Their jobs are unsecured and majority of the workers are not satisfied with their jobs in terms of welfare facilities and wages.

The study of terms of employment of workers proved that their terms and conditions need updation.

2) The third hypothesis "The Powerloom industry needs more Upgradation and Modernisation in the present scenario." has been proved true by the study of technology level of powerlooms.

The above said hypothesis was tested with the help of ChiSquare Test. The relevant variables were selected and two formulated sub-hypotheses were tested.

The first formulated hypothesis "Acquisition of Powerlooms is dependent on total investment" has been found valid. The critical value of the Chi Square at 0.05 level of confidence for 4 degree of freedom was 9.488 which is less than calculated value of Chi Square i.e. 28.614 hence the null hypothesis was rejected.

The second formulated hypothesis "Total Investment is dependent on Type of Looms" has been found valid. The critical value of the Chi Square at 0.05 level of confidence for 2 degree of freedom was 5.99 which is less than calculated value of Chi Square i.e. 52.898 hence the null hypothesis was rejected.

The decentralised powerloom sector plays a vital role in meeting the clothing needs of the country. The powerloom industry has the intrinsic strength not only to withstand but also progress in post WTO regime. But, the industry has to modernise itself not only in machinery sector but also in adopting newer technology in manufacturing, adopting newer marketing strategy and diversification towards new products.
India has ranked first in the total number of powerlooms in the world. India has 0.50 lakh shuttleless powerlooms with ranking of 11 . While India's major competitor China has second position in the world in terms of number of powerlooms. But China has about 3.39 lakh shuttleless powerlooms with 1 st ranking. The growth rate of China's textile economy is faster than India. In Malegaon there are about 68 shuttleless powerlooms out of 1.5 lakh powerlooms. With the advent of globalised free-trade regime the Indian market is open for the other countries. The Indian powerloom industry has to face the competition from low cost and high quality textile products. So the pace of modernisation needs more speed.

It is clear that the powerloom industry need more upgradation and modernisation in the present scenario.

\section{OBSERVATIONS}

1) The Indian Textile Industry has a dominant position in the world and occupies significant position in Indian Economy. The Indian Textile Industry is extremely diverse, with the hand woven sector, mill sector, hosiery sector and decentralised powerloom sector.

2) Powerloom industry has a pre-eminent position in the Indian economy. The sector contributes significant share in the production of cloth and generation of employment. There are about 22.05 laky powerlooms distributed over about 05 laky units, till 2008-2009. The Indian Powerloom Industry contributes $60.39 \%$ of the total powerlooms in the world. It also contributes $62 \%$ of the total cloth production \& provides employment to 52.65 laky persons.

3) The powerloom industry is spread all over India. The major states are Maharashtra, Tamil Nadir, Gujarat, Andhra Pradesh, Uttar Pradesh, Madhya Pradesh, Punjab, Rajasthan, Karnataka, and Hiragana. The Maharashtra state is the pioneering in the powerloom industry in India. The Maharashtra state has about 11.06 laky powerlooms out of 22.05 laky powerlooms in the country. The major clusters in Maharashtra are Bhiwandi, Malegaon, Ichalkaranji, Solapur and Nagpur.

4) In Maharashtra, about $95 \%$ of the total powerlooms are located in five major clusters i.e. Bhiwandi, Malegaon, Ichalkaranji, Solapur \& Nagpur. Out of 11.06 laky powerlooms 10.47 laky powerlooms are located in these five major clusters.

5) Malegaon was a traditional handloom centre of Maharashtra state. There are about 1.5 laky powerlooms installed in 7500 units. It is famous for its cheap grey cloth. There are about 75,000 workers engaged in the industry. The main products of the industry are cotton grey fabric, manmade fibre grey fabric and dyed fabrics (i.e. Lungi \& Saree).The daily production is about 75 laky meters.

6) The organisational structure of the powerloom industry in Malegaon is dominated by the small units of powerlooms. Mostly powerloom units have 4 to 24 powerlooms. The proprietorship pattern is leading in the powerloom industry in Malegaon About $70 \%$ weavers 
are working as a Job Worker under the Master weavers.

7) In Malegaon, majority of the powerlooms are conventional plain powerlooms. Near about 500 powerlooms having semi automatic technology and about 68 automatic shuttleless powerlooms are in Malegaon

8) The product profile of the powerloom industry is $60 \%$ Manmade Fibre Grey Fabrics, 35\% Cotton Grey Fabrics and $05 \%$ Dyed Fabrics i.e. Lungi \& Saree.

9) Yarn is the main component in the cost of production. The percentage of cost of production for yarn is; manmade fibre grey fabrics, $79.42 \%$ to $81.41 \%$; cotton grey fabrics, $86.10 \%$ to $88.53 \%$; dyed fabric - Saree, $87.02 \%$ to $90.28 \%$ \& dyed fabric- Lungi, $85.09 \%$ to $89.27 \%$.

There is no proper marketing mechanism in the Powerloom Industry in Malegaon. It was observed that, the price of the yarn and fabric always fluctuates. Sometimes it goes inverse direction, means the prices of the yarn increases while the prices of the fabrics goes down direction. As the majority of the weavers are job work weavers so they cannot afford buying yarn and marketing of the cloth. Middlemen enjoy the main profit \& they also exploit the weavers who are unorganised.

1) The main source of finance for the powerloom industry is Self Finance in Malegaon. Majority of the weavers belong to Muslim Community so they keep themselves away from usury. As per Islamic Shari (Laws) lending or borrowing on the basis of Interest is not allowed.

2) In Malegaon, the focal employment opportunity is Powerloom industry. As per government records, there are about 75,000 powerloom workers.

3) The terms and working condition of the powerloom workers are not favourable. Mostly weavers neglect to provide basic facilities as per Factory and Labour Laws.

4) The weavers of the Malegaon are not aware about the management skills in the area of marketing. They are mostly dependent on the middlemen. The weavers of Malegaon face not only marketing problem but they are exploited by the middlemen.

5) Shortage of raw material is also a hurdle for the powerloom industry. The shortage of raw material takes place because of two main reasons. When the export of cotton rises and another is artificial shortage by the yarn merchants/ commission agents.

6) There is only one spinning mill in Malegaon for the supply of raw material. The spinning mill is not sufficient for the supply of raw material. Further, the mill is also not running with their full utilisation.

7) The loom technology in Malegaon is outdated. The industry is running discarded and obsolete powerlooms. In Malegaon about $99 \%$ powerlooms are obsolete and outdated, which results in low productivity; cost of maintenance is high \& production of low quality fabrics.

8) The majority of the powerloom units are mostly small units. They run their business with small investment. Because of small scale they are not in a position to upgrade \& modernise their units.

9) The infrastructural facilities are not well developed. There is no sufficient infrastructure like road ways, truck terminals, railways etc.

10)In Malegaon, from the last ten years only 4 projects were sanctioned under Technology Upgradation Fund Scheme (TUFFS). In Malegaon $70 \%$ powerloom units are small working under master weavers with low capital and investment. The norms of the TUFFS are not suitable for the small weavers.

11) The state government has so far assisted the powerloom sector only for the powerloom co-operative societies. The state government's role is ignorant regarding decentralised powerloom sector. So far activities done by the government are not sufficient and development done only for the co-operative sector of powerloom industry is limited.

12) There is no awareness amongst the weavers regarding the schemes of the Central \& State governments.

13) The powerloom is facing problem of high rate of electricity and shortage of electricity. The rate of the electricity is high for the powerloom industry apart from that there is load shading of electricity daily.

14) There are about 110 powerloom co-operative societies in Malegaon. The co-operation form of organisation has not made much headway in the powerloom industry in Malegaon. They mostly depend on the government's financial assistance.

15)In Malegaon, Ministry of Textiles, Govt. of India established Powerloom Service Centre in 1976, which provides training facilities on pre - weaving and weaving technology. The centre also provides the testing facilities to check the quality parameter of the yarn. But most of the weavers are unaware about the centre.

\section{SugGeStions \& RECOMMENDATIONS}

To solve the problems of the Powerloom Industry of Malegaon and to come out of the prospects of industry the following suggestions and recommendations are given below:

1) Upgradation \& Modernisation: In Malegaon, the loom technology level used in the powerloom industry is awfully low. There are only 500 Semi Automatic and 68 Shuttles looms out of 1.5 laky powerlooms. The central government is running Technology Upgradation Fund Scheme for the modernisation of the powerloom industry. As most of the weavers are unaware about the scheme, there is a need of the hour to aware the weavers about the modernisation and upgradation of the industry.

2) Upgradation of Plain powerlooms to Semi-Automatic level: The majority of the powerloom owners are small weavers having 4 to 24 powerlooms. Because of small in size they are unable to get the benefits of modernisation scheme i.e. TUFFS. The government should initiate conversion of plain powerlooms to semi-automatic level. The plain looms can be converted by installing attachments of electrical / mechanical warp stop motion, weft stop motion and positive let off motion. The upgradation needs additional amount of Rs.15, 000 to Rs.20, 000 per powerloom.

3) Industrial Estate \& Textile Park: In order to pull the pace 
of the growth of the powerloom industry, the government should elevate it to the moderate industrial level. The government should develop and create the industrial estates or textile parks in the major clusters of the state.

4) Marketing Complexes: In Malegaon, marketing of the textile produce is one of the major problems of the weavers. They are exploited by the merchants \& commission agents. So the government should develop and encourage the Textile Marketing Complexes in which the government should control the pricing policies.

5) Processing Facilities: The major product of the powerloom industry is grey cloth which is semi finished. The weavers sell it without processing, so they can not enjoy the main profit. There are only two hand processing units in Malegaon. The government should provide infrastructural facilities to develop the Power Processing Units in Malegaon.

6) Electricity: The electricity board should ensure to supply uninterrupted power supply to the powerloom industry. The quality of the supply should also be constant. Because the voltage and frequency variations in Malegaon are stated to be very grave. The cost of the electric power is high for powerloom industry. Considering the predominance of small powerloom weavers with weak capital and input capacity, the state government may consider provision of concessional power for small weavers.

7) Product Diversification: The majority of the weavers are producing grey fabrics. They should divert their production from grey cloth to dyed fabrics and home textiles.

8) Technical Training: The workers employed in powerloom industry are mostly technically untrained. They acquire the skills through experience. Because of non-technical training their productivity is affected. Labour productivity can be further enhanced by providing systematic training to the powerloom workers. The Powerloom Service Centre, technical institutes and textile department should conduct special technical training programmes for the workers.

9) Technical Institute: In Malegaon, Powerloom Service Centre is only institution which provides technical training to the powerloom workers, which is not sufficient for the powerloom industry. The government should initiate to promote textile education in the city by starting technical institutions with specialisation in textile.

10)Financial Institution: Adequate, timely and cheap financial facilities should be provided by the financial institutions. On the lines of NABARD special financial institution for textile sector should be formed for the financial help of the sector.

11)Role of State Government: The state government so far played a moderate role in the development of powerloom co-operative societies in the state. The state government should also focus on the other segment of the powerloom industry. The state government issued Textile Policy Draft 2000 but till now it is not finalised.
The State Government should release the Textile Policy for the state earliest.

12)Entrepreneurial Training: In order to improve the level of managerial and administrative skills of the weavers. There is a need to expand the services of powerloom service centres. They should also provide training to proprietors/ weavers regarding entrepreneurship. Steps should be taken to provide basic entrepreneurial training to weavers.

13)Major Clusters' Study: A comprehensive survey of the powerloom industry in different clusters of the state should be conducted so as to recognize the major problems of the industry. This will help in the policy making regarding the powerloom industry.

14)Census of Powerloom Industry: Census of the powerloom industry should be conducted after every five years in which basic statistics of their needs, raw material, growth etc. should be conducted. It will be more effective for the programming and implementation of schemes.

15)Co-operative Organisation: The co-operative form of organisation should be strengthened and the Maharashtra government should actively participate in the promotion of Powerloom Co-operative Societies.

16) Awareness about Powerloom Service Centre: Most of the weavers are unaware about the powerloom service centre. The centre should organise awareness campaigns about the services provided by them. The government should strengthen the powerloom service centre in terms of capacity and infrastructural facilities.

17) Awareness about Government Schemes: There is need to create mechanism of awareness regarding the government schemes. The mechanism should be in such a way that weavers can take benefits from the schemes.

18)Factory Working Conditions: The weavers should emphasise on the working conditions in the factory. They should provide; arrangement for ventilation, exhaust fans to exclude dust and fumes, proper regular cleanliness, basic hygienic facilities, health and safety measures according to Factory Act 1948 \& Maharashtra Factories Rules 1963.

19)Terms of Employment: The weavers should enforce the Industrial \& Labour Laws for the welfare of the powerloom workers. They should provide basic facilities in the factory for the workers.

\section{REFERENCES}

[1] Alexndar B. (1921). The Powerloom and the Art of Weaving Dundee: James P. Mathew \& Co.

[2] Ansari A.M. (2007). Critical study of the Powerloom Co-operative Societies in Malegaon (with special reference to the management, organisation and marketing problems) since 1990 - 2007 (Unpublished Ph.D. thesis). Pune University, Pune.

[3] Ansari R.R. (1984). A Study of Marketing problems of Powerloom Industry in Malegaon City of Nasik District (Unpublished M.Phil dissertation). Nagpur University, Nagpur.

[4] B. Sahoo (1993). Problems and Prospects of Textile Industry. New Delhi: Mittal Publications, p.154

[5] Babbie, Earl (2001). The Practice of Social Research. California: Belmont, WADA Worth Publication Co. Inc.

[6] Bion B. H. \& Miller Upton. (1970). Introduction to Business Finance. New York: McGraw Hill Book Co. 
[7] Borg W.R. \& J.P.Gall. (1989). Educational Research: An Introduction. USA: Longman Pub. Co.

[8] C.Rajendra Kumar.(2008). Research Methodology, New Delhi: APH Publishing Corporation. p. 1

[9] Carlos C.Lorenzama M.A. (1993) Management Theory and Practice. Quezon City: Rex Printing Co. Inc. p.4

[10] Chorghade S.V. (1976). Powerloom Industry in Maharashtra (Unpublished Ph.D. thesis). Nagpur University, Nagpur.

[11] Dolle. B.M. (1992). A study of Socio Economic Problems of Powerloom industry in Malegaon (Unpublished Ph.D. thesis) University of Pune, Pune

[12] Fink, A. (2005). How to Conduct Surveys : A Step-by-Step Guide $\left(3^{\text {rd }}\right.$ ed.). Thousand Oak CA: Sage

[13] Gay L.R. \& Peter Airasian. (2000). Educational Research Competencies for Analysis and Application. New Jersey: Prentice Hall Inc.

[14] Ghosh G. K. \& Ghosh S. (1995). Indian Textiles : Past and Present. New Delhi: A.P.H. Publishing House

[15] Goode \& Hatt. (1953). Methods in Social Research. New Delhi: Prentice Hall, McGraw Hill - p.281

[16] Graeme Drummond \& John Ensor. (2005). Introduction to Marketing Concepts. Oxford: Elsevier Butterworth-Heinemann. p. 2

[17] Groppelli A.A. \& Nikbakht Ehsan. (2006). Finance. New York: Barron's Educational Series Inc.

[18] H.R. John. (2003). An Introduction to THE study of industrial relations (Vol-5). London: Routledge, p.95

[19] Husain Ashiq. (1996). Business Finance. Nairobi: East African Educational Publishers Ltd.

[20] Inamdar D. R. Kshire V. K. (1986). District Planning in India. New Delhi Oxford \& I. B. H. Pub.

[21] Area (Unpublished Ph.D. thesis). Shivaji University, Kolhapur.

[22] Jitendra S. B. (2009). Assessing the Prospects of India's Textile and Clothing Sector. New Delhi : National Council of Applied Economic Research

[23] Johan B., Johan S. \& Annekie B. (2007). Introduction to Marketing. Cape Town: Juta and Co Ltd. p-23

[24] Khandelwal N.M. (1985). Working Capital Management in Small Scale Industries. New Delhi: Ashish Publishing House. p.5

[25] Klemp L. \& Reddies B. (1992). Women Textile Workers Demand Justice: On the situation of the Textile \& Garment Industry in the Countries of the South. Germany: Friedrich Ebert Foundation.

[26] L.V. Redman and A.V.H. Mory. (1923). The Romance of Research. p.10.

[27] Maheshwari R.P. (2004). Principles of Business Studies. New Delhi: Pitambar Publishing Co. (P) Ltd. p.176

[28] Marsden R. (1895). Cotton Weaving: Its Development, Principles, and Practice. George Bell \& Sons, p.10,
[29] Mathur. D. C. (1993). Personnel Problems and Labour Welfare: A study of cotton textile industry. New Delhi: Mittal Publications. p.145

[30] Milan S. (2006). Textile Industry of India \& Pakistan. New Delhi: A. P. H. Publishing Corporation

[31] Najib C. Fatayerji.(2004). Electronic Marketing: Advantages \& Disadvantages. Florida: Roca Raton. p.4

[32] Ojha P.R. (1978). Corporate Dividend Policy in Indian Cotton Textile Industry. Allahbad : Kitab Mahal. pp. 75-104.

[33] Omkar Goswami. (1985). Indian Textile Industry 1970-1984: An Analysis of Demand and supply. Economic and Political Weekly, XX , No.38, Sept. 21 1985, 1610-1612

[34] P.C. Tulsian. (2007). Cost Accounting. New Delhi: Tata McGraw Hill Companies. p.3.33

[35] P.S. Mohana Kumar. (1997). Cotton Textile Industry. New Delhi: Reliance Publishing House. p.197

[36] Rakshit A. K. (2007). Powerloom Sector in India. Textile Review Volume 2 Issue 6 June 2007

[37] Rao Y. N. (1994). Financing of Cotton Textile Industry in India New Delhi: Ashish Publishing House.

[38] Richard M. (1895). Cotton Weaving Its Development, Principles and Practices. London: Charles Whittingham and Co.

[39] Roberto G. M. (1988). Business Finance. Quezon City: Rex Printing Company. p.107

[40] S.K. Dutta. (1991). Co-operative societies \& rural development: A politico- economic study. New Delhi: Mittal Publication. p. 2

[41] Sharma K.P. (2009). Entrepreneurship. New Delhi: V. K. Enterprises. p. 64

[42] Sharma R. K. (1997). Industrial Labour in India. New Delhi: Atlantic Publishers and Distributors. p.181

[43] Singla R.K. (2009). Business Management. New Delhi: V. K. (India) Enterprises. p.67

[44] Sowell E.J. and R.J.Casey. (1982). Analyzing Educational Research.", New York Belmont CA: Wadsworth.

[45] Sundararanajn S. (1991). Dimensions of Co-operative Movement. New Delhi: Mittal Publications. p.11

[46] Suundarapandian. M. (2002). Growth and Prospects of Handloom Sector in India. Mumbai: NABARD. p. 11

[47] Textile Commissioner. (2006). Handbook of Powerloom Industry. New Delhi: Ministry of Textiles, Govt. of India.

[48] Textile Commissioner. (2007). TUFS Manual. Mumbai: Office of the Textile Commissioner. p. 4

[49] Textile Committee. (1996). A survey of various aspects of the powerloom sector of textile industry in Maharashtra. Mumbai: Textile Committee, GOI.

[50] Thelma J. Talloo. (2008). Business Organisation and Management. New Delhi: Tata McGraw Hill Pub. Co. Ltd. p.166 